DANIEL E. LACH

\title{
KRYTERIA „KOSZTOWE” KWALIFIKOWANIA ŚWIADCZEŃ OPIEKI ZDROWOTNEJ JAKO GWARANTOWANYCH A PRAWO DO OCHRONY ZDROWIA
}

\section{WPROWADZENIE}

Jest rzecza powszechnie znana, że od kilku dekad koszty opieki zdrowotnej drastycznie rosna. Z jednej strony wynika to z postępu naukowego i technicznego: lekarze są w stanie zdiagnozować i podjać (coraz częściej skuteczna) terapię w stosunku do wielu wcześniej nieznanych lub nieuleczalnych chorób, pomocne sa w tym nowe technologie, urządzenia oraz leki. Postęp ma jednak także swe mroczne oblicze - szereg chorób wiąże się z zanieczyszczeniem środowiska i rozwojem cywilizacyjnym. Należy także zwrócić uwagę na zmiany demograficzne. W starzejącym się społeczeństwie przybywa osób potrzebujących opieki zdrowotnej, i to przez coraz dłuższy czas, gdyż średnia długość życia nieustannie wzrasta. Nie wolno także pomijać kwestii pozamedycznych. W działaniach reklamowych od dłuższego czasu można zaobserwować wykorzystywanie zjawiska tzw. marketingu strachu, strategii pozwalającej sprzedać usługi lub towary, często o ograniczonej lub wręcz zerowej skuteczności, w wyniku wywołania u konsumentów wrażenia, że nieskorzystanie z takiej oferty odbije się negatywnie na ich zdrowiu. Klasycznym przykładem sa tzw. paraleki, „suplementy diety”, reklamowane jako panaceum na wszelkie (w tym także budzące wątpliwości co do ich istnienia ${ }^{1}$ ) dolegliwości. Chodzi jednak także o rozmaite świadczenia tzw. medycyny alternatywnej oraz wyroby paramedyczne.

Można mieć nadzieję, że podmiot władzy publicznej, który decyduje o (współ)finansowaniu ze środków publicznych określonych świadczeń lub leków, czyni to na podstawie analizy merytorycznej, abstrahując od ewentualnego lobbingu lub zabiegów marketingowych. Nie wolno jednak nie doceniać wpływu takich działań na beneficjentów systemu opieki zdrowotnej, którzy są przecież także wyborcami. Nie bez znaczenia jest również istnienie drogi sądowej i możliwość konstruowania (odrębną kwestią jest, czy skutecznych) roszczeń o pokrycie kosztów terapii zgodnie np. z prawem do ochrony zdrowia. Tu pojawia się istotne rozgraniczenie. Dość łatwo jest - politycznie oraz prawnie - odrzucić żądanie umieszczenia w katalogu świadczeń gwarantowanych,

\footnotetext{
${ }^{1} \mathrm{~Np}$, „zakwaszenie organizmu”.
} 
a w konsekwencji także sfinansowania, niepotwierdzonej naukowo terapii lub medykamentu. Sprawa znacznie komplikuje się wtedy, gdy chodzi o uznane i skuteczne (choć często w minimalnym stopniu), ale bardzo kosztowne metody leczenia: np. terapie onkologiczne ${ }^{2}$ lub stosowanie tzw. sierocych produktów leczniczych ${ }^{3} \mathrm{w}$ odniesieniu do chorób rzadkich ${ }^{4}$, przede wszystkim genetycznie warunkowanych chorób przemiany materii. Wyprzedzając dalsze rozważania, można uznać, że - jak się wydaje - także w takich sytuacjach należałoby odmówić skuteczności żądaniom ich sfinansowania ze środków publicznych wyprowadzanym z prawa do (ochrony) zdrowia.

Przepisy regulujące zasady i tryb kwalifikowania świadczeń opieki zdrowotnej jako świadczeń gwarantowanych wprowadzono do ustawy z 27 sierpnia 2004 r. o świadczeniach opieki zdrowotnej finansowanych ze środków publicznych ${ }^{5}$ w 2009 r. W odrębnych opracowaniach przedstawiono ewolucję idei „koszyka świadczeń” oraz zgłoszono zastrzeżenia dotyczące, m.in., zgodności przyjętych rozwiązań dotyczących współfinansowania świadczeń gwarantowanych z zasadą równego - bez względu na sytuację materialną - dostępu do świadczeń opieki zdrowotnej ${ }^{7}$. Celem niniejszego opracowania jest natomiast omówienie problematyki tych kryteriów kwalifikowania świadczeń opieki zdrowotnej jako gwarantowanych, które odnoszą się do skutków finansowych dla systemu opieki zdrowotnej lub „kosztu uzyskania dodatkowego roku życia skorygowanego o jakość” (QALY - por. niżej pkt II.2). Owe „kosztowe” kryteria mogą uzasadniać decyzję o wyłączeniu określonych świadczeń lub leków z katalogu świadczeń gwarantowanych (a właściwie ich „niewłączeniu” do tego katalogu). Na tym tle pojawia się kwestia oceny wynikającego z tego faktu ograniczenia zakresu ustawowej gwarancji w świetle konstytucyjnoprawnych regulacji dotyczących prawa do ochrony zdrowia (art. 68 ust. 1 Konstytucji RP)

2 Warto podkreślić, że lek stosowany w ramach chemioterapii, dla którego wydana już została decyzja administracyjna o objęciu refundacją (tzn. pozytywnie rozważono przedmiotowe kryteria kosztowe - por. niżej pkt II.2), jest wydawany świadczeniobiorcy bezpłatnie (art. 6 ust. 8 ustawy z 12 maja 2011 r. o refundacji leków, środków spożywczych specjalnego przeznaczenia żywieniowego oraz wyrobów medycznych).

${ }^{3}$ Niektóre stany chorobowe występują tak rzadko, że koszt opracowania i wprowadzenia na rynek produktu leczniczego mającego służyć diagnozowaniu, zapobieganiu lub leczeniu takiego stanu chorobowego nie zostałby zwrócony z przewidywanej sprzedaży tego produktu leczniczego; przemysł farmaceutyczny niechętnie podejmowałby się opracowania leku w normalnych warunkach rynkowych; takie produkty lecznicze nazywane sa "sierocymi”, por. pkt 1 preambuły do rozporządzenia (WE) nr 141/2000 Parlamentu Europejskiego i Rady z 16 grudnia 1999 r. w sprawie sierocych produktów leczniczych (Dz. Urz. UE L 018, 22/01/2000, s. 0001-0005).

${ }^{4}$ Choroby rzadkie to takie, których częstość występowania nie przekracza progu pięciu chorych na 10 tysięcy osób (por. art. 3 ust. 1 rozporządzenia nr 141/2000), przy czym wszystkie te choroby mają charakter poważny, przewlekły i często zagrażają życiu. Znanych jest ok. 8000 takich chorób, a stale odkrywane są nowe: http://www.raredisease.org.uk/what-is-a-rare-disease/ [dostęp: 31.12.2016].

5 T.jedn.: Dz. U. 2016, poz. 1793 ze zm. (dalej jako: u.ś.o.z.).

${ }^{6}$ Por. D. E. Lach, Zasada równego dostępu do świadczeń opieki zdrowotnej, Warszawa 2011, s. 258-265.

7 Por. D. E. Lach, Koszyk świadczeń gwarantowanych w systemie opieki zdrowotnej, „Praca i Zabezpieczenie Społeczne” 2009, nr 12. 
oraz obowiązku władzy publicznej zapewnienia obywatelom równego dostępu do świadczeń opieki zdrowotnej finansowanej ze środków publicznych (art. 68 ust. 2 Konstytucji RP) ${ }^{8}$.

\section{KRYTERIA KWALIFIKOWANIA ŚWIADCZEŃ JAKO OBJĘTYCH (WSPÓŁ)FINANSOWANIEM ZE ŚRODKÓW PUBLICZNYCH}

\section{Kwalifikowanie świadczeń opieki zdrowotnej jako gwarantowanych}

Jak już wskazywano ${ }^{9}$, na mocy art. 31 b ust. 1 u.ś.o.z. kwalifikacji świadczenia opieki zdrowotnej jako świadczenia gwarantowanego w zakresie podstawowej opieki zdrowotnej; ambulatoryjnej opieki specjalistycznej; leczenia szpitalnego; opieki psychiatrycznej i leczenia uzależnień; rehabilitacji leczniczej; świadczeń pielęgnacyjnych i opiekuńczych w ramach opieki długoterminowej; leczenia stomatologicznego; lecznictwa uzdrowiskowego ratownictwa medycznego; opieki paliatywnej i hospicyjnej; świadczeń wysokospecjalistycznych oraz programów zdrowotnych dokonuje minister właściwy do spraw zdrowia po uzyskaniu (niewiążącej) rekomendacji Prezesa Agencji Oceny Technologii Medycznych i Taryfikacji, biorąc pod uwagę kryteria określone w art. 31a ust. 1 u.ś.o.z. Kryteria te obejmują nie tylko (1) wpływ na poprawę zdrowia obywateli przy uwzględnieniu: priorytetów zdrowotnych, wskaźników zapadalności, chorobowości lub śmiertelności określonych na podstawie aktualnej wiedzy medycznej, (2) skutki następstw choroby lub stanu zdrowia, w szczególności prowadzących do: przedwczesnego zgonu, niezdolności do samodzielnej egzystencji w rozumieniu przepisów o emeryturach i rentach z Funduszu Ubezpieczeń Społecznych, niezdolności do pracy w rozumieniu przepisów o emeryturach i rentach z Funduszu Ubezpieczeń Społecznych, przewlekłego cierpienia lub przewlekłej choroby, obniżenia jakości życia oraz (3) znaczenie dla zdro-

8 Dla porządku należy zaznaczyć, że niniejsze rozważania dotyczące zakresu ustawowej gwarancji w kontekście prawa do ochrony zdrowia mają charakter prawny. Znaczący dorobek filozofów prawa oraz (bio)etyków, dotyczący prawa do opieki zdrowotnej i jego zakresu, może być jedynie zasygnalizowany, gdyż chodzi przede wszystkim o opracowania doktryny amerykańskiej dyskutującej kwestie, które wobec pozytywnej regulacji prawa socjalnego w państwach europejskich, w tym w Polsce, są bez prawnego znaczenia (por. np. G. Outka, Sprawiedliwość społeczna i równy dostep do opieki zdrowotnej; Ch. Fried, Równość i prawa w opiece zdrowotnej; J. F. Childress, Prawo do opieki zdrowotnej?; A. Buchanan, Prawo do akceptowalnego minimum opieki zdrowotnej, wszystkie opracowania w: W. Galewicz (red.) Sprawiedliwość w medycynie, cz. 1: Wokót prawa do opieki zdrowotnej, Kraków 2015). Nie zmienia to faktu, że intrygujące sa rozważania, prowadzone m.in. w odniesieniu do kryterium QALY, w których dyskutuje się filozoficzne założenia rozmaitych koncepcji rozdziału zasobów oraz doboru pacjentów do udzielenia limitowanych świadczeń (por. np. N. Rescher, Alokacja świadczeń w ramach zaawansowanych terapii ratujacych życie; A. Williams, Nierówności zdrowotne i sprawiedliwośc międzypokoleniowa, wszystkie opracowania w: W. Galewicz (red.) Sprawiedliwość w medycynie, cz. 2: Dystrybucja zasobów w opiece zdrowotnej, Kraków 2015).

9 Por. D. E. Lach, Zasada..., s. 263 i n. 
wia obywateli, przy uwzględnieniu konieczności: ratowania życia i uzyskania pełnego wyzdrowienia, ratowania życia i uzyskania poprawy stanu zdrowia, zapobiegania przedwczesnemu zgonowi, poprawiania jakości życia bez istotnego wpływu na jego długość. Pod uwagę bierze się nadto - co oczywiste (4) skuteczność kliniczną i bezpieczeństwo, jak również (5) stosunek uzyskiwanych korzyści zdrowotnych do ryzyka zdrowotnego. Na liście znalazły się jednak także kryteria „kosztowe”: (6) stosunek kosztów do uzyskiwanych efektów zdrowotnych i (7) skutki finansowe dla systemu ochrony zdrowia, w tym dla podmiotów zobowiąanych do finansowania świadczeń opieki zdrowotnej ze środków publicznych ${ }^{10}$. Jest to o tyle zrozumiałe, że system opieki zdrowotnej, jako instytucja zabezpieczenia społecznego, ma służyć (częściowej - w przewidzianym ustawowo zakresie) kompensacie skutków wystapienia ryzyka niezdrowia polegających na konieczności poniesienia kosztów leczenia. Zadaniem systemu, a właściwie jego organizatora/wykonawcy, jest zatem gromadzenie przeznaczonych na ten cel środków i zarządzanie nimi zgodnie z przepisami ustawy (w tym zwłaszcza zawieranie ze świadczeniodawcami umów o udzielanie świadczeń opieki zdrowotnej), a nie zapewnianie obywatelom jakiegoś abstrakcyjnego poziomu zdrowia lub przejęcie finansowania wszelkich możliwych świadczeń.

\section{Decyzja o objęciu leku refundacją}

Z kolei gdy idzie o pozostałe zakresy świadczeń wskazane w art. 15 ust. 2 u.ś.o.z., to art. 31 b ust. 2 u.ś.o.z. odsyła do przepisów ustawy z 12 maja 2011 r. o refundacji leków, środków spożywczych specjalnego przeznaczenia żywieniowego oraz wyrobów medycznych ${ }^{11}$. W odniesieniu do leków, środków spożywczych specjalnego przeznaczenia żywieniowego oraz wyrobów medycznych dostępnych w aptece na receptę; programów lekowych określonych $\mathrm{w}$ przepisach ustawy o refundacji oraz leków stosowanych w chemioterapii określonych w przepisach ustawy o refundacji art. 12 u.r. nakazuje brać pod uwagę: (1) stanowisko Komisji Ekonomicznej, o której mowa w art. 17 u.r., (2) rekomendację Prezesa Agencji, o której mowa w art. 35 ust. 6 u.r., (3) istotność stanu klinicznego, którego dotyczy wniosek o objęcie refundacją, (4) skuteczność kliniczną i praktyczną, (5) bezpieczeństwo stosowania, (6) relację korzyści zdrowotnych do ryzyka stosowania, (7) stosunek kosztów do uzyskiwanych efektów zdrowotnych dotychczas refundowanych leków, środków spożywczych specjalnego przeznaczenia żywieniowego, wyrobów medycznych, w porównaniu z wnioskowanym, (8) konkurencyjność cenowa, (9) wpływ na wydatki podmiotu zobowiązanego do finansowania świadczeń ze środków publicznych i świadczeniobiorców, (10) istnienie alternatywnej

10 Podmiotami systemu ochrony zdrowia są nadto świadczeniobiorcy oraz świadczeniodawcy, należy zatem brać pod uwagę także skutki finansowe występujące po ich stronie. Na przykład uznanie określonego świadczenia za gwarantowane może pociagać za sobą konieczność poniesienia przez świadczeniodawców określonych wydatków na wyposażenie, dodatkowy personel, szkolenia itp., względnie wymagać udziału własnego świadczeniobiorcy.

11 T.jedn.: Dz. U. 2016, poz. 1536 ze zm. (dalej jako: u.r.). 
technologii medycznej, w rozumieniu ustawy o świadczeniach, oraz jej efektywność kliniczną i bezpieczeństwo stosowania, (11) wiarygodność i precyzję oszacowań wspomnianych kryteriów, (12) priorytety zdrowotne określone w przepisach wydanych na podstawie art. 31a ust. 2 u.ś.o.z., (13) wysokość progu kosztu uzyskania dodatkowego roku życia skorygowanego o jakość, ustalonego w wysokości trzykrotności Produktu Krajowego Brutto na jednego mieszkańca ${ }^{12}$, a w przypadku braku możliwości wyznaczenia tego kosztu - koszt uzyskania dodatkowego roku życia, biorąc pod uwagę inne możliwe do zastosowania w danym stanie klinicznym procedury medyczne, które moga być zastapione przez wnioskowany lek, środek spożywczy specjalnego przeznaczenia żywieniowego, wyrób medyczny ${ }^{13}$. Warto zauważyć, że w odniesieniu do leków zwraca się uwagę nie tylko na kwestie finansowe rozumiane jako wydatki podmiotu zobowiązanego do finansowania świadczeń ze środków publicznych oraz świadczeniobiorców ${ }^{14}$. Wprowadzono także kryterium „kosztu uzyskania dodatkowego roku życia skorygowanego o jakość” $\left(Q_{A L Y}{ }^{15}\right)$. Oznacza to, że przy podejmowaniu decyzji o refundacji ${ }^{16}$ właściwy minister może stwierdzić, że nawet w sytuacji, gdyby koszty terapii były możliwe do udźwignięcia przez system, to są one zbyt wysokie z punktu widzenia jakości skutków terapii. Jak się wydaje, można w tym widzieć odniesienie do zasady dobra wspólnego, nawiąującej do solidarności wspólnoty świadczeniobiorców: zdołalibyśmy sfinansować leczenie danego pacjenta, ale - co zabrzmi okrutnie - niewiele by mu to dało, dlatego rozsądniej jest wydać zaoszczędzone w ten sposób środki na więcej tańszych świadczeń dla większej ilości pacjentów.

12 Aktualnie (grudzień 2016) próg ten wynosi 125955 zł (3 x 41985 zł), por. Komunikat Prezesa Agencji Oceny Technologii Medycznych i Taryfikacji w sprawie obowiązujacej od 4 listopada 2015 r. wysokości progu kosztu uzyskania dodatkowego roku życia skorygowanego o jakość, http://wwwold.aotm.gov.pl/index.php?id=1064 [dostęp: 29.12.2016].

13 Por. także J. Adamski, K. Urban, E. Warmińska, Refundacja leków, środków spożywczych specjalnego przeznaczenia żywieniowego oraz wyrobów medycznych. Komentarz, Lex 2014, komentarz do art. 12 .

${ }^{14}$ Należy wskazać, że art. 12 pkt 9 u.r. jest zredagowany inaczej niż art. 31a ust. 1 pkt 7 u.ś.o.z., pominięto w nim świadczeniodawców, gdyż decyzje refundacyjne nie wpływają na poziom ich wydatków.

${ }^{15}$ Wskaźnik ten oparty jest na liczbie lat uzyskanych dzięki interwencji medycznej oraz jakości życia tych lat. Wynik jest uzyskiwany przez mnożenie współczynników, z których pierwszy oznacza liczbę lat, o którą wydłużone zostanie życie pacjenta dzięki danej procedurze. Druga zmienna oznacza subiektywne odczucie satysfakcji z życia w skali od 0 do 1.0. Uwzględnia ona status zdrowotny, psychospołeczny oraz socjologiczny badanej osoby. Uzyskuje się ja, pytając pacjenta, na ile lat życia w pełnym zdrowiu zamieniłby 10 lat życia przy obecnym stanie zdrowia (http://www.zdrowie.abc.com.pl/artykuly/aotmit-koszt-uzyskania-dodatkowego-roku-zycia-na-poziomie-nie-wiecej-niz-125-955-zl,9780.html; dostęp: 29.12.2016). Szerzej por. Wytyczne przeprowadzania Oceny Technologii Medycznych (HTA), Kraków-Warszawa marzec 2007, http:// wwwold.aotm.gov.pl/assets/files/wytyczne_hta/2007/Wytyczne_HTA_w_AOTM_03_2007.pdf [dostęp: 29.12.2016].

${ }^{16}$ Dla porządku należy zauważyć, że jest to także kryterium brane pod uwagę przez Komisję Ekonomiczną przy rozpatrywaniu wniosków o objęcie refundacją i ustalenie urzędowej ceny zbytu leku, środka spożywczego specjalnego przeznaczenia żywieniowego, wyrobu medycznego; podwyższenie lub obniżenie względnie ustalenie albo zmianę urzędowej ceny zbytu leku, por. art. 19 u.r. 


\section{OGRANICZENIE ZAKRESU USTAWOWEJ GWARANCJI JAKO NARUSZENIE PRAWA DO OCHRONY ZDROWIA}

W tym kontekście pojawia się kwestia konstytucyjnego prawa do ochrony zdrowia pacjenta, którego - wobec kalkulacji kosztów - pozbawia się (w ramach systemu opieki zdrowotnej) określonego leczenia. Zasadne jest pytanie, czy w takiej sytuacji mógłby on skutecznie zarzucić naruszenie tego prawa (np. w ramach skargi konstytucyjnej, której przedmiotem byłyby przepisy ustawy zdrowotnej, na podstawie których ostatecznie orzeczono o odmowie udzielenia/ sfinansowania terapii wyłączonej z zakresu ustawowej gwarancji z uwagi na kryteria kosztowe).

Prima facie wydaje się, że odpowiedź musi być twierdząca: zdrowie (i życie) człowieka jako dobra (wartości) najwyższe warunkują przecież możliwość korzystania przez niego z innych praw i wolności. Należy także przywołać wyrok Trybunału Konstytucyjnego z 7 stycznia 2004 r., K 14/0317, w którym wskazano, że w przepisie art. 68 ust. 2 zd. 1 Konstytucji RP „nie chodzi o dostępność jedynie formalna, deklarowaną przez przepisy prawne o charakterze "programowym", ale o dostępność rzeczywista, stanowiącą realizację określonego w ust. 1 art. 68 Konstytucji prawa do ochrony zdrowia [wyróżnienie - D.E.L.]”. Trybunał wskazał, że „nie widzi podstaw do odstapienia od poglądu wyrażonego w sprawie K 2/98 [...], według którego z art. 68 ust. 1 Konstytucji należy wywieść podmiotowe prawo jednostki do ochrony zdrowia. Treścia prawa do ochrony zdrowia nie jest naturalnie jakiś abstrakcyjnie określony [i w gruncie rzeczy niedefiniowalny (...)] stan »zdrowia» poszczególnych jednostek, ale możliwość korzystania z systemu ochrony zdrowia, funkcjonalnie ukierunkowanego na zwalczanie i zapobieganie chorobom, urazom i niepełnosprawności”.

W tym kontekście trzeba jednak przypomnieć ${ }^{18}$, że uzasadnieniem złożonej treści i struktury art. 68 Konstytucji RP, w którym ustrojodawca użył sformułowań zarówno „ochrona zdrowia” (ust. 1), jak i „opieka zdrowotna” (ust. 2), jest okoliczność, że relacja między nimi jest taka jak między całością a elementem. W związku z tym uprawniona wydaje się teza, że poszczególne ustępy art. 68 Konstytucji RP powinny być interpretowane łacznie: artykuł ten jako całość dotyczy zadań władzy publicznej określonych jako „ochrona zdrowia”, przy czym ust. 2-5 „dopełniaja postanowienia ust. 1, jednakże w sumie nie wyczerpuja treści pojęcia prawo do ochrony zdrowia”19. „Ochrona zdrowia” obejmuje bowiem w istocie całość działań państwa, podejmowanych w interesie ogólnym i indywidualnym, związanym z kwestią zdrowia publicznego (m.in. choroby społeczne, szczepienia, zagadnienia sanitarno-epidemiologiczne, krwiodawstwo, transplantologia), wykonywaniem zawodów medycznych,

17 Dz. U. 2004, Nr 5, poz. 37, OTK-A 2004, nr 1, poz. 1.

18 Por. D. E. Lach, Zasada..., s. 140; por także M. Safjan, L. Bosek (red.), Konstytucja RP, t. 1: Komentarz do art. 1-86, Warszawa 2016, komentarz do art. 68, nb. 74 oraz 84-96.

19 Por. J. Trzciński, Konstytucyjne prawo do zdrowia na tle art. 35 Karty Podstawowych Praw Unii Europejskiej, w: L. Garlicki, A. Szmyt (red.), Sześć lat Konstytucji Rzeczypospolitej Polskiej. Doświadczenia i inspiracje, Warszawa 2003, s. 302. 
funkcjonowaniem rynku usług zdrowotnych i podmiotów je świadczacych, a nawet dotyczaccym kwestii ekologicznej (art. 68 ust. 4 Konstytucji RP) czy rozwoju kultury fizycznej (art. 68 ust. 5 Konstytucji RP). Wiąże się ona jednak nie tylko z szeroko rozumianą polityką społeczna, realizowaną m.in. poprzez tworzenie określonych instytucji prawa pracy (np. regulacje dot. BHP) czy też zabezpieczenia społecznego, w tym systemu opieki zdrowotnej. Przecież to art. 68 ust. 1 (w zw. z art. 30 i 38) Konstytucji RP stanowi podstawę aksjologiczną np. do wyodrębniania grupy czynów zabronionych ze względu na ochronę życia i zdrowia (por. rozdział XIX k.k. zatytułowany „Przestępstwa przeciwko życiu i zdrowiu"), tworzenia regulacji chroniącej interesy konsumentów (por. ustawa z 12 grudnia 2003 r. o ogólnym bezpieczeństwie produktów ${ }^{20}$ ), czy też przepisów stawiajacych określone wymagania dla wyrobów projektowanych i wytwarzanych (por. ustawa z 12 września 2002 r. o normalizacji ${ }^{21}$ ).

Przywołujac na tym tle obowiązek władzy publicznej zapewnienia obywatelom równego dostępu do świadczeń opieki zdrowotnej finansowanej ze środków publicznych, wystarczy ograniczyć się do przypomnienia ${ }^{22}$, że z przepisu art. 68 ust. 2 Konstytucji RP można wyinterpretować normę kompetencyjna, adresowaną do władzy ustawodawczej i nakazującą skonstruować taki system opieki zdrowotnej, który uwzględnia jako podstawową dyrektywę równość dostępu, a jednocześnie, z uwagi na treść art. 68 ust. 3 Konstytucji RP, przewiduje uprzywilejowanie niektórych podmiotów ${ }^{23}$. Obowiązek nałożony na władze publiczne nie może być wykładany w kierunku publicznego prawa podmiotowego, które przysługuje obywatelom. Niemniej trzeba uznać, że z obowiązu tego wynika refleks prawa przedmiotowego odnoszący się do istoty (ang. core) nałożonego na władze publiczne obowiązku. Ową istotą (minimum) jest nakaz stworzenia przez władze publiczne systemu opieki zdrowotnej, który jest finansowany ze środków publicznych i zapewnia równy dostęp do świadczeń opieki zdrowotnej, to znaczy że ilość i jakość (standard) świadczeń oraz zasady ich udzielania (problem współfinansowania świadczeń gwarantowanych) nie sa zależne od sytuacji materialnej ani stopnia finansowej partycypacji (przede wszystkim składkowej, ale także udziału własnego) danego uprawnionego.

Co ważne: z uwagi na treść i charakter prawny art. 68 ust. 2 Konstytucji RP (norma programowa ${ }^{24}$ o strukturze zasady - nakazu optymalizacyjnego) zdefiniowany w tym przepisie cel - równość dostępu - powinien być realizowany w sposób maksymalny. Wyraźnie trzeba natomiast podkreślić, że wskazanym konstytucyjnie celem nie jest maksymalizacja zakresu gwarantowanych świadczeń. Priorytet przyznano bowiem uniezależnieniu dostępu od sytuacji materialnej obywateli, co prowadzi do wniosku, że konstrukcja systemu i za-

20 T.jedn.: Dz. U. 2016, poz. 2047.

21 T.jedn.: Dz. U. 2015, poz. 1483.

${ }_{22}$ Zagadnienie to było wielokrotnie omawiane, ostatnio: D. E. Lach, Zasada równego dostępu do świadczeń opieki zdrowotnej, w: idem (red.), Konstytucyjnoprawne wytyczne dla konstruowania systemów opieki zdrowotnej w Niemczech i w Polsce, Kraków 2016.

${ }^{23}$ Por. B. Banaszak, Konstytucja Rzeczypospolitej Polskiej. Komentarz. Warszawa 2012, komentarz do art. 68 , nb. 4-9.

${ }^{24}$ Odmiennie por. M. Safjan, L. Bosek (red.), op. cit., komentarz do art. 68, nb. 2-4 oraz 76. 
kres gwarancji winny być instrumentem wyrównania społecznego w ramach solidarnej wspólnoty.

W konsekwencji można dojść do wniosku, że czym innym jest wyprowadzana przez Trybunał Konstytucyjny z art. 68 ust. 1 Konstytucji RP „rzeczywista możliwość korzystania z systemu ochrony zdrowia”, która dotyczy ochrony zdrowia w jej szerokim znaczeniu, czym innym zaś - dostęp do świadczeń opieki zdrowotnej finansowanej ze środków publicznych w ramach systemu zabezpieczenia społecznego, który ma być równy - niezależny od sytuacji materialnej obywateli - natomiast warunki i zakres udzielania świadczeń precyzować ma ustawa. Trzeba bowiem uznać, że prawo do ochrony zdrowia nie oznacza możliwości dochodzenia (od kogo i na czyj koszt: władzy publicznej? organizatora systemu opieki zdrowotnej?) wszelkich możliwych świadczeń opieki zdrowotnej. Natomiast nałożony na władze publiczne w art. 68 ust. 2 Konstytucji RP obowiązek ustanowienia systemu opieki zdrowotnej opartego o zasadę równego dostępu, niekonkretyzujący jednak ani formy organizacyjno-finansowej, ani - co ważne - zakresu przedmiotowego, powinien być rozumiany właśnie jako nakaz stworzenia instrumentu służącego realizacji prawa do ochrony zdrowia w jego indywidualnym i świadczeniowym wymiarze, zwiazanym z koniecznościa pokrycia kosztów leczenia. Urzeczywistnianie prawa jednostki do ochrony zdrowia w sytuacji wystapienia ryzyka niezdrowia odbywa się w zatem ramach systemu opieki zdrowotnej i na zasadach go konstruujących. Jeżeli system został ukształtowany zgodnie z wytycznymi z art. 68 ust. 2 Konstytucji RP, to nie można skutecznie zarzucać przewidzianemu w nim ograniczeniu przedmiotowemu, że wyłączając z zakresu ustawowej gwarancji określone świadczenia, narusza tym samym prawo zainteresowanych nimi osób do ochrony zdrowia.

\section{PRAWO DO OCHRONY ZDROWIA JAKO PODSTAWA ROSZCZENIA O UDZIELENIE/SFINANSOWANIE ŚWIADCZEŃ NIEOBJĘTYCH SYSTEMOWĄ GWARANCJĄ}

Nawet jednak jeśli dojść do wniosku, że regulacja ustawy, konkretyzując zakres ustawowej gwarancji, może także wyłączać niektóre świadczenia z uwagi na kryteria „kosztowe”, nie naruszając tym samym prawa do ochrony zdrowia, trzeba zmierzyć się z powszechnym przekonaniem, że zdrowie stanowi wartość, która nie powinna być wyceniana pieniężnie. Tego rodzaju argumentacja legła u podstaw żywo dyskutowanego w doktrynie niemieckiej ${ }^{25}$

${ }^{25}$ Por. m.in.: U. Becker, Das Recht auf Gesundheitsleistungen, w: G. Manssen, M. Jachmann, Ch. Gröpl (Hrsg.), Nach geltendem Verfassungsrecht: Festschrift für Udo Steiner zum 70. Geburtstag, Stuttgart-München- Hannover-Berlin-Weimar-Dresden, Boorberg 2009; J. Nimis, Leistungspflicht der gesetzlichen Krankenkassen für neue Behandlungsmethoden - 8 Jahre Nikolausentscheidung des BVerfG, „Die Krankenversicherung” 2013, s. 229 i n.; A. Penner, A. Bohmeier, Die Umsetzung des Nikolaus-Beschlusses durch die Sozialgerichtsbarkeit, „Wege zur Sozialversicherung" 2009, s. 65 i n.; J. Joussen, § 2 Abs. 1a SGB V - Die Umsetzung des Nikolausbeschlusses 
orzeczenia niemieckiego trybunału konstytucyjnego (Bundesverfassungsgericht - BVerfG) znanego jako „uchwała mikołajkowa" ${ }^{26}$. Trybunał, odnosząc się do żądania sfinansowania ze środków instytucji ubezpieczeniowej wybranej przez ubezpieczonego metody leczenia (która nie została jednak uznana medycznie ani też przez powołane do tego organy ubezpieczenia zdrowotnego), skonstruował bezpośrednie roszczenie ubezpieczonego oparte na prawach podstawowych: $\mathrm{z}$ art. 2 ust. 1 (prawo do swobodnego rozwoju osobowości) w związku z art. 20 ust. 1 i art. 28 ust. 1 zd. 1 (zasada państwa socjalnego) oraz z art. 2 ust. 2 niemieckiej ustawy zasadniczej (prawo do życia i nietykalności cielesnej). Jako warunek wskazał jednak, aby w odniesieniu do zagrażającej życiu lub na ogół śmiertelnej choroby nie było powszechnie uznanej i odpowiadającej standardom medycznym terapii, a istniała nie całkiem odległa perspektywa wyleczenia lub odczuwalnego pozytywnego wpływu na przebieg choroby wskutek zastosowania tej metody leczenia ${ }^{27}$.

$\mathrm{Na}$ tym tle pojawia się zatem kolejna kwestia: czy beneficjent systemu opieki zdrowotnej (lub nawet podmiot niebędący świadczeniobiorca) mógłby na podstawie konstytucyjnego prawa do ochrony zdrowia konstruować roszczenie o udzielenie/sfinansowanie świadczeń nieobjętych systemową gwarancja, a koniecznych/zasadnych medycznie?

Jak się wydaje, na tak sformułowane pytanie należałoby odpowiedzieć przecząco. $\mathrm{Z}$ zakazu narażania życia lub zdrowia dla realizacji innych celów oraz nakazu ich ochrony nie da się bowiem przekonująco wywieść obowiązku finansowania określonych świadczeń ze środków publicznych gromadzonych w ramach systemu opieki zdrowotnej opartego na solidarności społecznej, i to bez żadnych ograniczeń, czy to kwotowych, czy to dotyczacych medycznej skuteczności żądanej terapii ${ }^{28}$. Tak szerokie rozumienie prawa do ochrony zdrowia $\mathrm{z}$ art. 68 ust. 1 Konstytucji RP oznaczałoby w istocie, że przepis art. 68 ust. 2 Konstytucji RP pozbawiony jest znaczenia, gdyż uregulowane ustawowo kwestie zakresu podmiotowego i przedmiotowego systemu opieki zdrowotnej, jego organizacji i finansowania świadczeń musiałyby ustapić wobec absolutnego roszczenia wyprowadzanego z ogólnoludzkiego prawa do ochrony zdrowia.

W tym kontekście warto przywołać orzeczenie szwajcarskiego trybunału federalnego ${ }^{29}$ dotyczące kwestii pokrycia przez ubezpieczenie zdrowotne kosztów leku stosowanego przy leczeniu rzadkiej choroby przemiany materii (choroba Morbusa Pompego), oddziałującej w szczególności na muskulaturę. Półtoraroczna terapia, dla której nie ma alternatywnej metody, sprawiajaca, że odcinek drogi pokonany przez pacjenta w ciagu 6 minut spaceru z około

des BVerfG, „Die Sozialgerichtsbarkeit” 2012, s. 625 i n. Przegląd orzeczeń nawiązujących do „uchwały mikołajkowej” znajduje się na stronach Instytutu Prawa Socjalnego i Zdrowotnego Ruhr-Universität Bochum (http://www.nikolaus-beschluss.de). Por. także S. Huster, Sprawiedliwość (społeczna) w niemieckim ustawowym ubezpieczeniu zdrowotnym, w: D. E. Lach (red.), op. cit., s. 102 i n.

${ }^{26}$ Orzeczenie z 6 grudnia 2005 r. (stąd nazwa: Der Nikolaus-Beschluss), 1 BvR 347/98.

${ }^{27}$ Por. BVerfGE [Zbiór urzędowy orzeczeń niemieckiego trybunału konstytucyjnego] 115, 25 i n.

${ }^{28}$ Por. S. Huster, op. cit., s. 105-107.

${ }^{29}$ Orzeczenie z 23 listopada 2010, 9C_334/2010, http://www.bger.ch/index/juridiction/jurisdiction-inherit-template/jurisdiction-recht/jurisdiction-recht-urteile2000.htm [dostęp: 29.12.2016]. 
330 metrów poprawia się o 28 metrów; kosztuje jednak w skali roku około 500000 CHF. Oddalając skargę ubezpieczonej na odmowę pokrycia tych kosztów przez instytucję ubezpieczeniowa, trybunał szwajcarski przywołał zasadę gospodarności świadczeń (Wirtschaftlichkeit) ${ }^{30}$ i wskazał, że „kwestia kosztów nie może być zepchnięta na margines prostym stwierdzeniem, że gdy idzie o ludzkie zdrowie, rozważania o kosztach byłyby etycznie lub prawnie niedopuszczalne. Środki finansowe, które społeczeństwo ma do dyspozycji w celu spełniania społecznie pożądanych zadań, nie są nieskończone. Środki, które zostana wydane na określone cele, nie moga zostać przeznaczone na inne, także pożądane, zadania. Dlatego nie można realizować celu bez uwzględnienia finansowego kosztu, lecz należy wymierzyć relację kosztu i korzyści oraz kosztu i gospodarności. Dotyczy to także opieki zdrowotnej”" ${ }^{1}$. Ponadto trybunał przywołał wprost zasadę równości praw (Rechtsgleichheit), wskazując, że sprzeciwia się ona poniesieniu określonych kosztów w jednostkowym przypadku, jeżeli koszt taki nie mógłby być poniesiony w odniesieniu do wszystkich ewentualnych przypadków (nicht verallgemeinerungsfähig). Ustalił bowiem, że gdyby chcieć zastosować żądane leczenie w odniesieniu do wszystkich osób, które musza żyć z podobnie ograniczona jakościa życia jak skarżąca, to powstałyby przez to koszty w wysokości ok. 90 miliardów CHF, co ponadpółtorakrotnie przewyższa całe koszty systemu opieki zdrowotnej lub daje nieco więcej niż $17 \%$ całego produktu krajowego brutto Szwajcarii ${ }^{32}$. Innymi słowy, trybunał staną na - słusznym - stanowisku, że nie należy gwarantować w systemie świadczeń, których sfinansowanie w stosunku do wszystkich ewentualnych potrzebujacych byłoby niemożliwe.

Na marginesie można tylko dodać, że owa niemożliwość powinna dotyczyć nie tylko sytuacji przekroczenia budżetu systemu w ogóle, ale także poniesienia wydatków w takiej wysokości, która zagroziłaby sfinansowaniu udzielania świadczeniobiorcom innych świadczeń, w szczególności tych o charakterze elementarnym, podstawowym (przy uwzględnieniu priorytetów zdrowotnych, wskaźników zapadalności, chorobowości i śmiertelności, por. art. 31a ust. 1 pkt 1 u.ś.o.z.). W tym miejscu godzi się ponownie przywołać zasadę dobra wspólnego, oznaczająca prymat dobra wspólnoty beneficjentów nad interesem indywidualnego pacjenta: skapość środków finansowych pozostających w dyspozycji organizatora systemu uzasadnia wprowadzenie instrumentów, które ograniczają lub wyłączają dostęp do niektórych świadczeń, tak aby móc zagwarantować i sfinansować inne - „częściej” potrzebne większej liczbie uprawnionych.

${ }^{30}$ Zgodnie z art. 32 ust. 1 zd. 1 szwajcarskiej federalnej ustawy o ubezpieczeniu chorobowym (Bundesgesetz über die Krankenversicherung) świadczenia określone w art. 25-31 ustawy muszą być skuteczne, celowe i być spełniane w sposób gospodarny (Die Leistungen nach den Artikeln 2531 müssen wirksam, zweckmässig und wirtschaftlich sein). Odnośnie do tego kryterium por. np. D. E. Lach, Stosunki prawne między instytucjq ubezpieczenia zdrowotnego a świadczeniodawcami w Niemczech i w Polsce, „Ruch Prawniczy, Ekonomiczny i Socjologiczny” 67, 2005, z. 4.

${ }^{31}$ Por. orzeczenie z 23 listopada 2010 r, 9C_334/2010, nb. 7.5.

${ }^{32}$ Chodzi o dane z 2007 r., por. orzeczenie z 23 listopada 2010 r., 9C_334/2010, nb. 7.8. 


\section{KATALOG ŚWIADCZEŃ GWARANTOWANYCH JAKO INSTRUMENT „EKONOMIZACJI OPIEKI ZDROWOTNEJ”}

Nawiąując do przywołanej przez szwajcarski trybunał zasady gospodarności świadczeń, należy także zauważyć, że w polskim systemie opieki zdrowotnej katalog świadczeń gwarantowanych służy m.in. właśnie „ekonomizacji opieki zdrowotnej”33 rozumianej jako kosztowa optymalizacja działania systemu opieki zdrowotnej i relacji pomiędzy jego podmiotami. Jego celem jest bowiem nie tylko zapobieganie regionalnemu zróżnicowaniu dostępnych świadczeń (warunków ich realizacji) ${ }^{34}$, czy też jednoznaczne zdefiniowanie „warunków i zakresu udzielania świadczeń” 35 (art. 68 ust. 2 zd. 2 Konstytucji RP ${ }^{36}$. Należy przypomnieć, że w stanie prawnym przed wprowadzeniem regulacji definiujacej pozytywny „koszyk” świadczeń gwarantowanych można było konstruować swoiste domniemanie prawa do wszystkich świadczeń opieki zdrowotnej, z wyjątkiem wyłączonych expressis verbis przepisami ustawy. Jan Jończyk wskazywał: „na koszt publicznego funduszu zdrowia należy się wszystko, co nie jest prawnie wyłączone, a owe wyłączenia podlegaja, jako wyjątki, ścisłej wykładni; wyjątków nie można bowiem tworzyć w drodze rozszerzającej wykładni przepisów, a interpretacyjne wątpliwości należy tłumaczyć na korzyść zasady" ${ }^{37}$. Skreślenie art. 17 u.ś.o.z., który, obok art. 16 u.ś.o.z., był jednym z przepisów określających stosunkowo skromny katalog świadczeń wyłączonych z systemu, a tym samym rezygnacja z koncepcji „koszyka negatywnego” na rzecz „koszyka pozytywnego” oraz stworzenie rozbudowanej regulacji dotyczaceej kwalifikowania świadczeń opieki zdrowotnej jako świadczeń gwarantowanych, w tym ustanowienie kryteriów kosztowych, było świadomą decyzją ustawodawcy, zmierzajacca do wprowadzenia do systemu mechanizmów ekonomicznych służących kontroli i ograniczaniu kosztów ${ }^{38}$. Wobec ograniczoności zasobów będących w dyspozycji organizatora systemu opieki zdrowotnej „ekonomizacja opieki zdrowotnej” jest bowiem nie tylko dopuszczalna, ale wręcz konieczna.

${ }^{33}$ Por. I. Rudawska, Ekonomizacja relacji pacjent-ustugodawca w opiece zdrowotnej, Szczecin 2006.

${ }^{34}$ Por. uchwałę SN z 28 maja 2002 r., III UZP 3/02.

${ }^{35}$ Por. uchwałę SN z 24 stycznia 2007 r., III UZP 4/06.

${ }^{36}$ Nawiasowo tylko należy zauważyć, że jest to kompetencja ustawodawcy, ten jednak, w drodze delegacji ustawowej, przekazał ją władzy wykonawczej - ministrowi właściwemu do spraw zdrowia (art. 31a u.ś.o.z.).

${ }^{37}$ J. Jończyk, Glosa do uchwaty SN $z$ dnia 24 stycznia 2007 r., III UZP 4/06, OSP 2008, nr 4, s. 317.

${ }^{38} \mathrm{~W}$ tym kontekście należy przypomnieć, że jednym z zasadniczych elementów ustawy refundacyjnej jest ustanowienie całkowitego budżetu na refundację (przez co rozumieć należy wysokość środków publicznych przeznaczonych w planie finansowym NFZ na refundowane leki, środki spożywcze specjalnego przeznaczenia żywieniowego, wyroby medyczne), który zgodnie z art. 3 ust. 1 u.r. nie może wynosić więcej niż $17 \%$ sumy środków publicznych przeznaczonych na finansowanie świadczeń gwarantowanych w planie finansowym Funduszu, urzędową marżę hurtową w wysokości 5\% urzędowej ceny zbytu (art. 7 ust. 1 u.r.) oraz urzędową marżę detaliczną naliczaną od ceny hurtowej leku (art. 7 ust. 4 u.r.), por. D. E. Lach, Refundacja leków a równy dostep do świadczeń opieki zdrowotnej, „Ruch Prawniczy, Ekonomiczny i Socjologiczny” 76, 2014, z. 1. 


\section{PODSUMOWANIE}

Podsumowując, można uznać, że generalnie wyłączanie z katalogu świadczeń gwarantowanych określonych świadczeń lub leków z uwagi na skutki finansowe dla systemu opieki zdrowotnej lub koszt uzyskania dodatkowego roku życia skorygowanego o jakość jest w pełni uzasadnione. Wynika to nie tylko z faktu, że art. 68 ust. 2 Konstytucji RP w zd. drugim wprost uprawnia ustawodawcę do określenia zakresu przedmiotowego systemu opieki zdrowotnej, a stosowne przepisy ustawy przewiduja m.in. kryteria kosztowe kwalifikowania świadczeń gwarantowanych. Warte podkreślenia jest także i to, że ograniczanie katalogu świadczeń znajduje silne oparcie w zasadach konstruujących system opieki zdrowotnej. Po pierwsze, już z samej zasady równego dostępu do świadczeń wynika, że objęte ustawowa gwarancją powinny być tylko takie świadczenia, co do których w ramach systemu istnieje faktyczna możliwość ich udzielenia i sfinansowania na równych zasadach wszystkim potrzebującym ich świadczeniobiorcom. Po wtóre, należy wskazać, że system opieki zdrowotnej stanowi pewną wspólnotę, wprawdzie przymusowa, ale jednak solidarna, tzn. przejmująca ciężar finansowy świadczeń i uwspólniająca $\mathrm{w}$ ten sposób indywidualne ryzyka konieczności poniesienia kosztów leczenia. Efektem jest społeczne wyrównanie w ramach tej wspólnoty, w żadnym wypadku nie jest ono jednak bezbrzeżne, nieograniczone, absolutne. Nie można bowiem na koszt wspólnoty żądać ekstremalnie drogich świadczeń, których nie sposób w ramach funduszu wspólnoty zapewnić wszystkim. Solidarna wspólnota dba o dobro wspólne, które wobec ograniczoności środków nakazuje finansowanie w pierwszej kolejności świadczeń ilościowo dominujących - poszukiwanych najczęściej i przez największą grupę uprawnionych, a przekazywanie tylko ewentualnej nadwyżki na kosztowne świadczenia przeznaczone dla nielicznych. Można także wskazać na zasadę gospodarności, nakazująca jak najefektywniejsze wydatkowanie środków publicznych w ramach systemu opieki zdrowotnej, uwzględniające relację kosztu i korzyści.

Można zatem zasadnie stwierdzić, że odmowa udzielenia lub sfinansowania świadczenia lub leku nieobjętego ustawowa gwarancją nie narusza prawa do ochrony zdrowia. Uzasadniona wydaje się nadto teza, zgodnie z którą należałoby odmówić skuteczności ewentualnemu roszczeniu pacjenta konstruowanemu na podstawie tego prawa o sfinansowanie świadczeń spoza katalogu świadczeń gwarantowanych, czy to przez organizatora systemu opieki zdrowotnej, czy też np. skarb państwa. Ochronie i urzeczywistnieniu prawa do ochrony zdrowia w skonkretyzowanej sytuacji zindywidualizowanego uprawnionego wynikajacej z wystapienia ryzyka niezdrowia skutkujacego koniecznościa poniesienia kosztów leczenia służy bowiem system opieki zdrowotnej finansowanej ze środków publicznych, ustanowiony na podstawie normy kompetencyjnej z art. 68 ust. 2 Konstytucji RP. To w jego ramach i zgodnie z jego zasadami uprawnieni moga realizować swoje prawo do ochrony zdrowia $\mathrm{w}$ jego indywidualnym i świadczeniowym wymiarze. 


\section{THE CRITERIA OF 'COST' USED IN THE QUALIFICATION \\ OF GUARANTEED HEALTHCARE SERVICES \\ AND THE RIGHT TO HEALTH CARE}

\section{Sum mary}

The subject of this paper is the legal criteria for the procedure of qualifying healthcare services as guaranteed and subsequent reimbursement decisions, as well as the assessment of the admissibility of the exclusion of certain services or drugs from the catalogue of guaranteed services because of the financial implications for the healthcare system or the cost of obtaining an additional year of life. The latter cost is adjusted by the quality against the background of the constitutional regulations concerning the right to health care and the duty of the public authority to secure the citizens equal access to health care services financed from public funds in a frame of a healthcare system as an instrument for the realisation of 'the right to protection of health' in its individual and service-concerning meaning. The question of the limitation of the scope of the catalogue of guaranteed services as the violation of the right to protection of health and the possibility of giving a rise for a claim for the financing of services beyond the legal guaranty based on the right to protection of health is also discussed. 
